\title{
The Exorcist of Sombor. The Mentality of an Eighteenth-Century Franciscan Friar. By Dániel Bárth.
}

New York-London: Routledge, 2020. 294 pp.

\author{
Gábor Klaniczay \\ Department of Medieval Studies, Central European University, Quellenstraße 51, 1100, Vienna, \\ Austria; H-1051 Budapest, Nádor u. 9, Hungary; Department of Medieval History, Eötvös Loránd \\ University, H-1088 Budapest, Múzeum krt.6-8, Hungary; klanicz@gmail.com
}

Dániel Bárth's book, as indicated by the title, is written for scholars of the history of religion, of the history of mentalities, as well as for those who study popular belief. His choice of subject, the life story of the Southern Slavic Franciscan friar, Rochus Szmendrovich, who became famous and got in trouble for his exorcisms, invokes the quintessential monograph of a recently influential historical trend, 'microhistory', a classic written by Giovanni Levi and published in English under the title Inheriting Power: The Story of an Exorcist. ${ }^{1}$ Microhistory, the historian's version of Clifford Geertz's "thick description", can only be explored where there is an exceptional source-which is how Emmanuel Le Roy Ladurie was able to write, based on records from the Inquisition, the story of the early-fourteenth-century Pyrenean village, Montaillou, where Cathar prefects were hiding; or how Carlo Ginzburg wrote about the strange and original worldviews of the Italian miller, Menocchio, convicted as a heretic at the end of the sixteenth century. Bárth discovered a gem of this type fifteen years ago in the Archives of the Archdiocese of Kalocsa when he found a set of documents containing the letters of the eighteenth-century Franciscan exorcist and the decisions of the ecclesiastical investigation about him. In his introduction, he gives a vivid description of the 'big catch' and his own process. He tells us how his research transformed from the first studies, through a long and thorough archival investigation in Hungary and abroad, into a microhistorical-biographical monograph of the history of mentality, the final form of which was completed and published with the support of the European Research Committee (ERC) funded research project headed by Éva Pócs (Vernacular religion on the boundary of Eastern and Western Christianity: continuity, changes and interactions).

1 Levi, Inheriting Power. 
It is worth reviewing the structure of the book because, considering the recent historical and ethnographical scholarly literature, it offers unusual and ground-breaking solutions. Bárth starts by taking document "shards", i.e., eight "fragments", to reconstruct the adventurous life journey of the protagonist, Petrus/ Rochus Szmendrovich (1727-1782). He presents the colourful painted wooden panels (with folk representations of the Devil) the young Petrus might have seen in the chapel of Saint Barbara in Velika Mlaka, his native village near Zagreb. The author studied the Szmendrovich family tree originating from the noble circles of Turopolje of a special status. He describes the witchcraft hysteria sweeping across the region in 1733-1734 when Petrus was six years old, how he chose the clerical path at the age of 17, and how he served as the parish priest of Sesvete near Požega between 1756 and 1763. The surviving inventories of the diocesan visits inform us about Petrus's living environments and his everyday obligations, and they even mention two lists of his books. Bárth goes on to tell the reader how Szmendrovich joined the Franciscan Order at the age of 36, where he was given the monastic name, Rochus, and two years later, in 1766, he moved to Sombor, the venue of the book's central storyline, the series of exorcisms that led to the scandals and the ecclesiastical investigation. Finally, Bárth briefly discusses Rochus's activities as a catechist missionary after he was forced to leave Sombor, when he served as a priest near Čakovec. In the final years of his life, he was struggling with the problematic affairs of the charitable foundation he had created when leaving the parish of Sesvete.

The book focuses on a three-year period (1766-1769) when the congregation of the province appointed Rochus as an Illyrian preacher in Sombor, an ethnically and religiously mixed city. After a few months, he made himself noticed with a spectacular exorcism ritual: in December 1766, he exorcised the Devil from a Catholic woman called Anna who complained of demonic possession over the course of two weeks with a series of repeated rites; first at the sacristy, then at the church itself, in front of a large audience. The therapy provided by the exorcist priest gained popularity primarily with the 'schismatic' (Orthodox) population of the city; about thirty citizens went to see the friar with similar complaints. Rochus found nineteen of these cases justified and performed the exorcism; he allegedly managed to convert many of them to Catholic faith. For the church spectacle in Sombor, they even had a special elevation constructed for the participants of the ritual and for the 'audience.'

The unusual events divided fellow Franciscans, secular leaders, as well as the ecclesiastic magistrate and residents of the city. Besides the approving and supportive voices, there were also critical opinions; soon enough someone reported the friar to the superior ecclesiastical authority at the Archbishopric's Consistory at Kalocsa. The most exciting chapter of Bárth's book is the analysis of the investigation launched following the report, lasting for over two years and consisting of multiple rounds. 
In the first round, the dean of Upper Bács, Antonious Bajalich, hurried to the scene to gather first-hand information about the unusual rituals. He did a thorough investigation and found many irregularities in the secretly observed exorcism rituals. Thus, he consulted the minister of the Franciscan friary and the magistrate of the city. Finally, in the name of the archbishop's Holy See, he prohibited the continuation of exorcisms, and interrogated Father Rochus with a nine-point, critical and straightforward questionnaire. The latter was not shy with his defensive explanations-his descriptions reveal an unprecedentedly complex picture of the beliefs about demonic possession and the practice of exorcism in the age.

The unfolding investigation, however, took an unexpected turn: in April 1767, Father Rochus was indicted in front of the consistory of the archbishop of Kalocsa, and with the help of his supporters in Sombor, he managed to convince the members of the prelates' consistory of the acceptable nature of his activities. Therefore, they merely lightly reprimanded him and allowed him to pursue his exorcist activities on condition that he always asked for their permission beforehand, and gave his special justifications. There are two such 'legalised' exorcisms with Rochus's description of symptoms and accounts that give us a detailed picture, "like so many snapshots or fragmented frames from a film reel”- as Bárth puts it.

After a shorter, calmer period comes the third act: in May 1769, presumably following another report, Father Rochus was once again called to Kalocsa along with the two possessed subjects he was going to exorcise, a Hungarian woman and a Southern Slav Catholic man, as well as the local clerics supporting the Franciscan. The investigation by the consistory received detailed instructions from Archbishop József Batthyány himself; in addition, the county doctor also participated. This time the investigation ended with the humiliation and defeat of the exorcist. He was unable to 'prove' the demonic possession, and the consistory rather established 'natural causes' of the illnesses and prohibited any further exorcisms. Despite the months-long protests for Rochus by his supporters in Sombor, the Holy See stood by this decision, and the Franciscan province put an end to the scandals by transferring the friar to another location.

The biography, edited from the 'fragments' and the three-year-long exorcism saga of the first chapter makes up almost half of the book and is in itself a colourful, complete microhistory. However, it is followed by a detailed analysis of roughly the same proportions, divided into eight chapters. Bárth goes over the story over and over again, exploring its background in detailed analyses of social history, church history, and cultural history.

The ethnic and religious diversity of Sombor, a settlement "at the border of Western and Eastern Christianity", provides an important background to the phenomenon of the 'interconfessional' exorcism performed by a Catholic preacher to 
Orthodox believers, which offended some of the Catholics for being interconfessional. However, the enigmatic question of why it was among the Orthodox believers that the exorcist priest was so popular is left unanswered. In relation to this, I would like to suggest a few parallels: recent studies by Dóra Czégényi, Vilmos Keszeg, Tünde Komáromi, Éva Pócs, and Aurél Vajkai have discovered that in Transylvania, many of the Hungarian Calvinist and Catholic believers turn to the Greek Catholic priest, as a "priest with magical powers" whenever they want to curse or bewitch someone. That is, the magical services condemned in their own religion are accepted from the priest of another congregation, and are used if needed. Was it not something similar that happened at the end of the eighteenth century in the southern land when Orthodox believers turned to a Franciscan friar for exorcism?

Another issue of the history of religion and ideas is the problem of internal conflicts within the clerical hierarchy. Bárth approaches this topic following the popular guidelines of nouvelle histoire or "history from the bottom up", as E. P. Thompson once suggested. For this, an analysis was needed of the different preferences and the increasingly diverse religious views of the more "populistic" Franciscan Order and the hierarchically higher secular clergy on the one hand, and of the lower clergy and the administration of the Archbishopric of Kalocsa, on the other. Furthermore, the many divisive conflicts of interests and rivalries within the various religious communities had to be discovered as well. The result is a picture of the institution of 'monastic priesthood' in Sombor, of the inner division of the Franciscan convent, and of the followers and adversaries of Rochus.

The most important context of Rochus Szmendrovich's story is, without a doubt, the practice of exorcism, the interpretation of demonic possession and the associated, much debated consideration of demonology undergoing a change in the eighteenth century, and the Catholic Enlightenment and 'Counter-Enlightenment' -Bárth looks at all these in his analysis. The first two topics have recently caught the attention of Hungarian ethnographers. In 2012, Éva Pócs and András Zempléni organized a monumental international conference in Pécs about the historical and anthropological analysis of spirit possession, with the participation of such internationally acclaimed experts as Janice Boddy, Moshe Sluhovski, Sarah Ferber, Nancy Caciola, and Thomas Csordas. On this occasion, Bárth also presented the protagonist of his book-hopefully the conference volume will sooner or later also be published. Another sign of interest in the topic is the debate organized in 2013 by the Hungarian Ethnographical Society (by Dániel Bárth himself) and published in Ethnographia in 2014 about the paper of János Szulovszky, in which he contests Éva Pócs's approach to the analysis of spirit possession, and argues that the exorcism practices of the Church are still going on until this day. ${ }^{2}$

2 Szulovszky, "Lehet-e a szellemi néprajznak keresztény tudományos megközelítése?." 
When presenting more universal contextual connections, Bárth could rely on his own previous analyses, ${ }^{3}$ the most recent results of international research, and possible international parallels. One such parallel is the above-noted analysis by Giovanni Levi of the late-seventeenth-century exorcist from Piemonte, Giovan Battista Chiesa, which provided a good example of the anthropological interpretation of the history of the concepts of disease. Another example is the activity of the 'miracle doctor', Johann Joseph Gassner, presented in Eric Midelfort's book (Exorcism and Enlightenment). ${ }^{4}$ Gassner was a contemporary of Szmendrovich, whose medical practices treating tens of thousands of patients extended from traditional exorcism to the 'more modern' hypnosis. Besides these two contemporary cases, Bárth takes a detour to review the early modern history of exorcism and mentions the thus far sporadically documented early modern cases in Hungary.

One of the most exciting parts of the book is Bárth's arduous work to investigate the sources of irregularities that displeased the high clerical authorities investigating Rochus's exorcisms. He explains that the practice of exorcism, after the infamous and often scandalous early modern cases, was somewhat reduced over the course of the eighteenth century. For instance, the Flagellum daemonum by the Italian Girolamo Menghi (1644), available in several copies in Hungary at the time, was considered too 'superstitious' in the early eighteenth century and was put on the index. Based on the bibliographical indices of the Sesvete parish and the Franciscan convent's library and on Rochus's notes, Bárth reconstructs the possible readings of the exorcist and concludes that he was mostly relying on this very handbook, probably without being aware of it being prohibited. The dean questioning him, on the other hand, was well aware and even confiscated the book from him during the investigation. Bárth conducts a microscopical comparative analysis of the cases described in the demonological handbook and of the most characteristic symptoms of the patients treated by Rochus, examining why certain methods and certain ritual forms in the itemized exorcism liturgy may have seemed more effective in the eyes of contemporaries or of the priest performing the ritual. In his philological, epistemological, and anthropological analysis, Bárth also discusses why the exorcist's activities were so popular with the 'audience', what the "theatre of devilish strife" was like, and why despite all the disapproval Rochus insisted on public ceremonies.

Bárth concludes his volume by touching upon the wider context: with a brief review of the reform attempts of the Catholic Enlightenment also appearing in Hungary and of the recurrent protests of those rejecting the innovations. This process in a European context is called-following Max Weber-the "disenchantment of the world". In Hungary, it included banning witch-trials in this period, more

3 Bárth, Benedikció és exorcizmus a kora újkori Magyarországon.

4 Midelfort, Exorcism and Enlightenment. Johann Joseph Gassner. 
precisely in 1768, on the proposal of Empress Maria Theresa's personal physician, Gerard van Swieten, and the continuing fight against superstition under the rule of Joseph II, a process comprehensively explored in a recent monograph by Péter Tóth G., another member of the research group headed by Éva Pócs. ${ }^{5}$

Thanks to Dániel Bárth, the Church's investigation of the exorcisms of the Franciscan friar from Sombor has become the most thoroughly documented and most diversely analysed story of this great eighteenth-century transformation.

\section{Literature}

Bárth, Dániel. Benedikció és exorcizmus a kora újkori Magyarországon [Benediction and Exorcism in Early Modern Hungary]. Budapest: L'Harmattan, 2010.

Levi, Giovanni. Inheriting Power: The Story of an Exorcist. Chicago: University Press, 1988.

Midelfort, Eric. Exorcism and Enlightenment. Johann Joseph Gassner and the Demons of Eighteenth-Century Germany. New Haven-London: Yale University Press, 2005.

Szulovszky, János. "Lehet-e a szellemi néprajznak keresztény tudományos megközelítése?" [Can there be a Christian Scientific Approach of the Spiritual Ethnography?]. - With the responses by Éva Pócs, Gábor Klaniczay, Gábor Vargyas, and Tamás Mohay. Ethnographia 125 (2014): 161-215.

Tóth G., Péter. Boszorkánypánik és babonatéboly [Panic of Witches and Madness of Superstition]. Budapest: Balassi, 2020.

5 Tóth G., Boszorkánypánik és babonatéboly.

(c) 2021 The Author(s).

(c) (7) This is an open-access article distributed under the terms of the Creative Commons Attribution-Non Commercial 4.0 International Licence (CC BY-NC 4.0). 